\title{
IMPROVEMENT OF PRODUCTIVITY IN KUWAIT STEEL USING ERGONOMICS PARAMETERS BY CONTROLLING THE NOISE AND TEMPERATURE
}

\author{
Ehsaan-Reza BAGHERIAN \\ Inspection Technology \& Quality Assurance National Institute (ITQAN), Kingdom of Saudi Arabia, \\ ehsanreza@gmail.com
}

https://doi.org/10.37904/metal.2020.3446

\begin{abstract}
Metal casting is one of the most important manufacturing process technologies and is defined as a process in which molten or liquid metal is poured into a mould. Today, metal casting components are found in over 90 percent of manufactured goods and equipment, from critical component for aircraft and automotive industries to home applications as well as construction machineries. In a high competitive market, the productivity improvement is very important. The main aim of this work is to study the productivity improvement in Kuwait Steel Company using ergonomics factors such as noise and temperature. It is concluded that by considering the ergonomics the quality of products has improved and the productivity increased. It was found that, the productivity improved by $0.45 \%$ for controlling the temperature and $0.80 \%$ by controlling the noises.
\end{abstract}

Keywords: Productivity, Kuwait steel, ergonomic, noise, temperature

\section{INTRODUCTION}

\subsection{Productivity}

Productivity is an ability to produce a good or service. More specifically, productivity is the measure of how effectively resources are managed to complete timely objectives as stated in terms of quantity. Productivity is useful as a relative measure of actual output of production compared to the actual input of resources, measured across time or against common entities. Productivity is a measure of the rate at which outputs produced per unit of input. It is calculated as the ratio of the amount of outputs produced to the amount of inputs used [1]. Productivity describes various measures of the efficiency of production [2]. Productivity is a measure of the rate at which outputs of goods and services are produced per unit of input (labour, capital, raw materials, etc). It is calculated as the ratio of the amount of outputs produced to some measure of the amount of inputs used. Improving productivity can have connotations of economizing on the use of inputs for example, adopting efficient production processes that minimize waste. Equally, improving productivity can have connotations of yielding more output for example, using resources in activities or with technologies that generate more output [3].

\subsection{Ergonomic}

Ergonomics is redesigning a job to suit the worker so that the work is safer and more productive. Implementation of the study of ergonomic solutions can provide employees a better and comfortable working environment and also increase productivity. The temperature and noise are the most important vital factors that affect the performance of workers in casting industries [4,5]. Generally speaking ergonomics have many advantages in industries such as improves productivity and quality, employee engagement, increase saving. Ergonomics can reduce the primary risk factors and creates a better safety culture. So, this research presents an approach to improve productivity in metal casting to decrease mistakes of workers rate in the metal casting field by ergonomic and to increase safety and health rate in the workplace. Using a real-life example of Kuwait 
Steel Company which produce a metal billets as a final product by using metal casting techniques at Kuwait Steel company which is located in Al-Shuaiba industrial area in Kuwait [6]. This report will study and compare the average worker performance rate for the "Before" study period with the average worker performance rate of the "After" study period.

\section{EXPERIMENT}

This section presents the experimental work on two ergonomic parameters including noise and temperature.

\subsection{How to Calculate Productivity Improvements on Increased Production Levels?}

Productivity improvements on increased production levels can be calculated by the following steps:

a) Calculate the current productivity. This can be done by dividing the number of units completed by the number of hours spent on them. For example, if it takes two hours to complete the production of three units, then 1.5 units are produced per hour;

b) Introduce incentives, such as bonuses for higher productivity. Also examine areas where you can make the job easier for employees. If materials are placed far away from workers, move them closer. If poor lighting and noise cause fatigue, examine improvements that can make in the workplace. Choose the productivity improvements and implement them;

c) Measure productivity after improvements. Again, divide the number of units completed by the number of hours required to make them. After making improvements, it might find that four units were completed in two hours. The employees are now making two units per hour;

d) Subtract the old production rate from the new. In the example, employees produce two units per hour, an improvement of 0.5 . This is your production improvement figure;

e) Divide the production improvement figure by the old production rate and multiply by 100 to get a percentage. In the example, 0.5 divided by 1.5 equals 0.33 . Multiply by 100 to get $33 \%$. That figure is your improvement to productivity.

\subsection{Noise}

Ergonomic design is a way to fit the worker to the job by knowing their capabilities and limitations. Thus, the workplace is safer and more efficient which lead employees to feel more comfortable that will increase productivity. In addition, Ergonomic improvements can reduce the primary risk factors in the workplace. In Kuwait steel company, the conditions of the work atmosphere will increase the temperature and noise levels. So, working efficiency of worker is reduced. The problem begins when material loading in to the furnace. The electric furnace which has high performing is produces high noise when it melts the iron, the process takes shorter times for melting heat. But the worker cannot bear this. After the material is melt in the electric furnace it will go to The Ladle Furnace in this process the chemical composition will be adding to provide the product the mechanical properties that will give the steel the grades of international standards. Then once the desired chemical composition and temperature is reached, the steel is transferred to final process which is the Continuous Casting machine. During the transferring the higher temperature exists. This is simply explained to the processes of steel making, to control these two issues, we study the level of the noise and temperature in the surrounding area in different periods During the day. First of all, the level of the noise which can be measured in units known as decibels $(\mathrm{dB})$ level of noise exposure has different affected between people, so we can give level of noise that absolutely safe but in general daily noise exposure above $75-80 \mathrm{~dB}$ can cause hearing damage. As shown in Figure 1, the standard of the World Health Organization's recommended exposure limits of noise levels per day. So, the louder the noise is, the less time it takes to cause damage. Thus, the measurement of noise must be repeated at appropriate intervals to determining an employee's effective exposure. Table 1 will present the noise level before new design. 


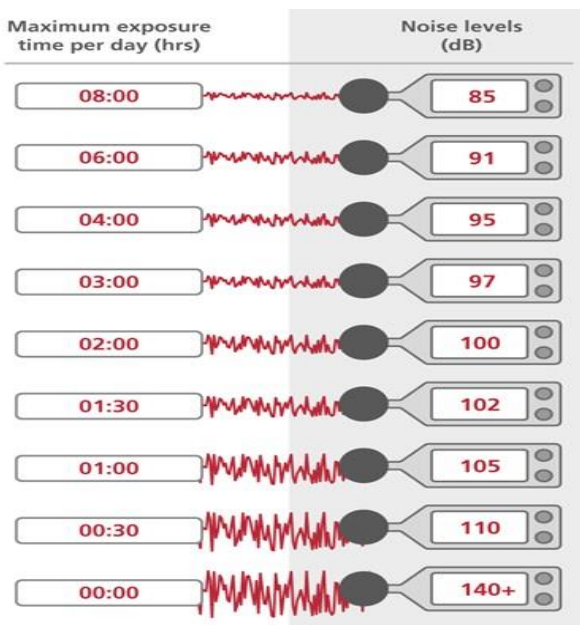

Figure 1 Standard of the World Health Organization

Table 1 Noise level before new design

\begin{tabular}{|c|c|c|c|c|}
\hline Shift /Hour & & & & Average \\
\hline \multicolumn{5}{|c|}{ Morning shift 7 a.m. - 3 p.m. } \\
\hline \multirow[t]{2}{*}{ Intervals } & 8-9 a.m. & 11 a.m.-12 p.m. & 2-3 p.m. & \multirow[b]{2}{*}{$92 \mathrm{~dB}$} \\
\hline & $88 \mathrm{~dB}$ & $90 \mathrm{~dB}$ & $98 \mathrm{~dB}$ & \\
\hline \multicolumn{5}{|c|}{ Afternoon shift 3 p.m.-11 p.m. } \\
\hline \multirow[t]{2}{*}{ Intervals } & 4-5 p.m. & 7-8 p.m. & 10-11 p.m. & \multirow[b]{2}{*}{$91.6 \mathrm{~dB}$} \\
\hline & $87 \mathrm{~dB}$ & $93 \mathrm{~dB}$ & $95 \mathrm{~dB}$ & \\
\hline \multicolumn{5}{|c|}{ Night shift 11 p.m.-7 a.m. } \\
\hline \multirow[t]{2}{*}{ Intervals } & 12-1 a.m. & 3-4 a.m. & 6-7 a.m. & \multirow[b]{2}{*}{$89.3 \mathrm{~dB}$} \\
\hline & $83 \mathrm{~dB}$ & $86 \mathrm{~dB}$ & $99 \mathrm{~dB}$ & \\
\hline
\end{tabular}

To reduce the noise exposure, we discussion some of important point with the Kuwait steel company such as they have to use proper work equipment, also do regular maintaining for work equipment. In addition, they should organization of work to limit duration and intensity of exposure and give adequate rest periods.

Table 2 present noise level after new design.

Table 2 Noise level after

\begin{tabular}{|c|c|c|c|c|}
\hline Shift /Hour & & & & Average \\
\hline \multicolumn{5}{|c|}{ Morning shift 7 a.m.-3 p.m. } \\
\hline \multirow[t]{2}{*}{ Intervals } & 8-9 a.m. & 11 a.m. -12 p.m. & 2-3 p.m. & \multirow[b]{2}{*}{$80.3 \mathrm{~dB}$} \\
\hline & $82 \mathrm{~dB}$ & $80 \mathrm{~dB}$ & $79 \mathrm{~dB}$ & \\
\hline \multicolumn{5}{|c|}{ Afternoon shift 3 p.m.-11 p.m. } \\
\hline \multirow[t]{2}{*}{ Intervals } & 4-5 p.m. & 7-8 p.m. & 10-11 p.m. & \multirow[b]{2}{*}{$81.6 \mathrm{~dB}$} \\
\hline & $77 \mathrm{~dB}$ & $82 \mathrm{~dB}$ & $86 \mathrm{~dB}$ & \\
\hline \multicolumn{5}{|c|}{ Night shift 11 p.m.-7 a.m. } \\
\hline \multirow[t]{2}{*}{ Intervals } & 12-1 a.m. & 3-4 a.m. & 6-7 a.m. & \multirow[b]{2}{*}{$81 d B$} \\
\hline & $83 \mathrm{~dB}$ & $81 \mathrm{~dB}$ & $79 \mathrm{~dB}$ & \\
\hline
\end{tabular}




\subsection{Temperature}

Second, as we know the high temperatures tend to impair human functions. Additionally, the rise in core temperature causes causing thermal discomfort. Table $\mathbf{3}$ and Table $\mathbf{4}$ indicating possible complications at varying levels of heat index values as the National Institute for Occupational Safety and Health (NIOSH) classified [7].

Table 3 Heat index associated protective measures for worksites

\begin{tabular}{|c|c|c|}
\hline Heat index & Risk level & Protective measure \\
\hline $\begin{array}{l}\text { Less than } 91^{\circ} \mathrm{F} \\
\left(33^{\circ} \mathrm{C}\right)\end{array}$ & Lower (caution) & Basic health and safety planning \\
\hline $\begin{array}{l}91^{\circ} \mathrm{F} \text { to } 103^{\circ} \mathrm{F} \\
\left(33^{\circ} \mathrm{C} \text { to } 39^{\circ} \mathrm{C}\right)\end{array}$ & Moderate & Implement precautions and heighten awareness \\
\hline $\begin{array}{l}103^{\circ} \mathrm{F} \text { to } 115^{\circ} \mathrm{F} \\
\left(39^{\circ} \mathrm{C} \text { to } 46^{\circ} \mathrm{C}\right)\end{array}$ & High & Additional precautions to protect workers \\
\hline $\begin{array}{l}\text { Greater than } 115^{\circ} \mathrm{F} \\
\left(46^{\circ} \mathrm{C}\right)\end{array}$ & Very high to extreme & Even more aggressive protective measures \\
\hline
\end{tabular}

Table 4 Effect of heat

\begin{tabular}{|c|c|c|}
\hline Celsius & Fahrenheit & Notes \\
\hline $27-32^{\circ} \mathrm{C}$ & $80-90^{\circ} \mathrm{F}$ & Caution: fatigue is possible with prolonged exposure and activity. Continuing \\
activity could result in heat cramps.
\end{tabular}

Moreover, Table 5 and Table 6 show the temperature measurement in Kuwait Steel Company before and after design.

Table 5 Temperature measurement before new design

\begin{tabular}{|c|c|c|c|c|c|}
\hline \multicolumn{7}{|c|}{ Morning shift } & \multirow{2}{*}{ Average } \\
\hline Hour & $8-9$ a.m. & $10-11$ a.m. & $12-1$ p.m. & $2-3$ p.m. & \\
\hline T outdoor & $24^{\circ} \mathrm{C}$ & $33^{\circ} \mathrm{C}$ & $39^{\circ} \mathrm{C}$ & $42^{\circ} \mathrm{C}$ & $34.5^{\circ} \mathrm{C}$ \\
\hline T indoor & $45^{\circ} \mathrm{C}$ & $48^{\circ} \mathrm{C}$ & $50^{\circ} \mathrm{C}$ & $53^{\circ} \mathrm{C}$ & $49^{\circ} \mathrm{C}$ \\
\hline \multicolumn{7}{|c|}{ Night shift } & \\
\hline Hour & $6-7$ p.m. & $8-9$ p.m. & $10-11$ p.m. & $1-2$ a.m. & \\
\hline T outdoor & $28^{\circ} \mathrm{C}$ & $26^{\circ} \mathrm{C}$ & $27^{\circ} \mathrm{C}$ & $22^{\circ} \mathrm{C}$ & $25.7^{\circ} \mathrm{C}$ \\
\hline T indoor & $42^{\circ} \mathrm{C}$ & $44^{\circ} \mathrm{C}$ & $48^{\circ} \mathrm{C}$ & $50^{\circ} \mathrm{C}$ & $46{ }^{\circ} \mathrm{C}$ \\
\hline
\end{tabular}

After applying our recommending in Kuwait steel company which are make the roof open so that the air will regenerate and installation more of barriers of heat insulation materials in front of furnaces. Table 6 shows the temperature measurement after new design. 
Table 6 Temperature measurement after new design

\begin{tabular}{|c|c|c|c|c|c|}
\hline \multicolumn{5}{|c|}{ Morning shift } & \multirow[t]{2}{*}{ Average } \\
\hline Hour & 8 - 9 a.m. & 10 - 11 a.m. & 12 - 1 p.m. & 2 - 3 p.m. & \\
\hline T outdoor & $24^{\circ} \mathrm{C}$ & $33^{\circ} \mathrm{C}$ & $39^{\circ} \mathrm{C}$ & $42^{\circ} \mathrm{C}$ & $34.5^{\circ} \mathrm{C}$ \\
\hline$T$ indoor & $34^{\circ} \mathrm{C}$ & $39^{\circ} \mathrm{C}$ & $41^{\circ} \mathrm{C}$ & $45^{\circ} \mathrm{C}$ & $39.7^{\circ} \mathrm{C}$ \\
\hline \multicolumn{5}{|c|}{ Night shift } & \\
\hline Hour & 6 - 7 p.m. & 8 - 9 p.m. & 10-11 p.m. & 1 - 2 a.m. & \\
\hline T outdoor & $28^{\circ} \mathrm{C}$ & $26^{\circ} \mathrm{C}$ & $27^{\circ} \mathrm{C}$ & $22^{\circ} \mathrm{C}$ & $25.7^{\circ} \mathrm{C}$ \\
\hline T indoor & $41^{\circ} \mathrm{C}$ & $38^{\circ} \mathrm{C}$ & $35^{\circ} \mathrm{C}$ & $33^{\circ} \mathrm{C}$ & $36.7^{\circ} \mathrm{C}$ \\
\hline
\end{tabular}

\section{RESULTS AND DISCUSSION}

The Relationship between the productivity and two factor which are noise level and temperature is an inverse relationship because when the noise level and temperature increase the productivity will decrease and this is what we proved through the result we get after calculating the yield.

Factory production during the first month was around 100,000 Ton per month it approximates 3,333.3 Ton per day before any improve. For the noise level improve the production rate increases to 100,450 Ton per month that approximate $3,348.3$ Ton per day. Thus, the productivity increases by $0.451 \%$. Then the production rate for the temperature improve increases to 100,800 Ton per month that approximate 3,360 Ton per day.

So, the productivity increases by $0.80 \%$. Finally, when we compare the two factor the result show that the temperature has more effect on the worker in the factory than the noise level. Figure 2 and Figure $\mathbf{3}$ present the comparison data.

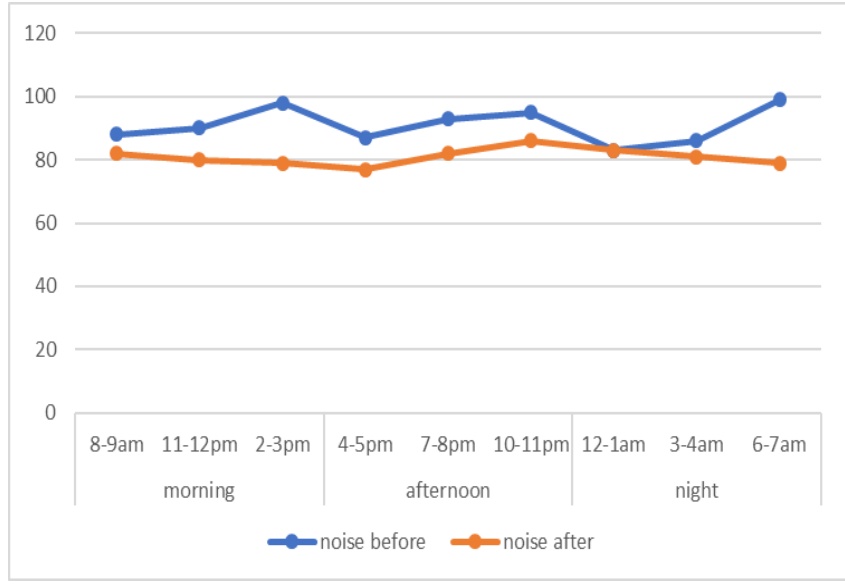

Figure 2 Noise level before and after new design

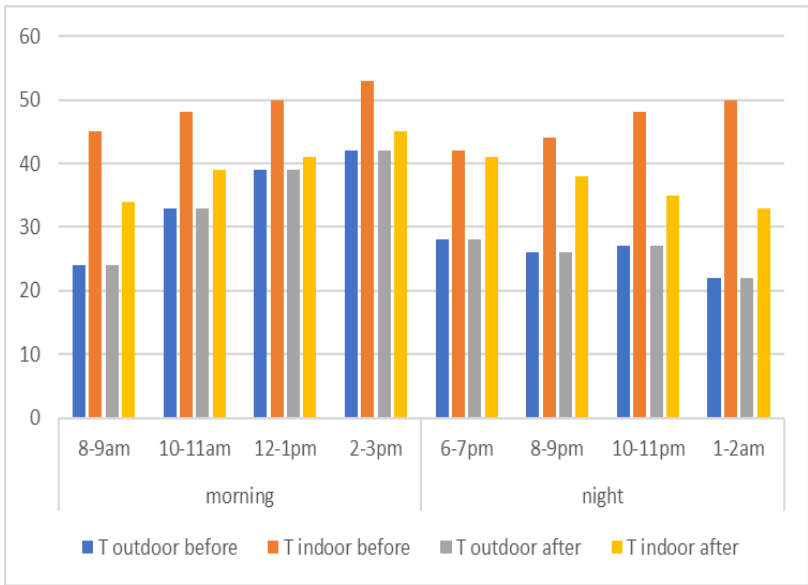

Figure 3 Chart of the temperature measurement

\section{CONCLUSION}

From the experimental results and their analysis, the following conclusions can be drawn:

1) It is concluded that by considering the ergonomics the quality of products has improved and the productivity increased;

2) It was found that, the productivity improved by $0.45 \%$ for controlling the temperature and $0.80 \%$ by controlling the noises;

3) As for future work, this research can be extended by investigation into the influence of other parameters or other important factors which can be enhance on productivity such as employee motivation. 


\section{ACKNOWLEDGEMENTS}

This research project would not have been possible without the support of Kuwait Steel engineers and American University of the Middle East. Their guidance helped us throughout this research. The authors would like to thank to Chairman of company for his valuable comments and suggestions to improve the quality of the paper.

\section{REFERENCES}

[1] ZAGADE D.D, DULANGE S.R. Productivity Improvement Techniques for Casting. International Journal on Recent and Innovation Trends in Computing and Communication. 2015, vol. 3, issue 4 pp. 1950-1952.

[2] SICKLES, R., ZELENYUK, V. Measurement of Productivity and Efficiency: Theory and Practice. Cambridge: Cambridge University Press, 2019. https://doi.org/10.1017/9781139565981.

[3] DANIEL R.M., DHAVAL P., PRASHANT P., RATHWA D. Productivity Improvement of Casting Industry Using Kaizen and 5S Techniques - A Case Study on Ebenezer Alloys. International Journal of Advance Research in Engineering Science \& Technology. 2016, vol. 3, issue 5, pp. 512-526.

[4] DEOUSKAR N. The impact of ergonomics on the productivity of people. International Journal of Marketing \& Financial Management. 2017, vol. 5, issue 6, pp 59-63.

[5] PICKSON R.B., BANNERMAN S., AHWIRENG P.O. Investigating the Effect of Ergonomics on Employee Productivity: A Case Study of the Butchering and Trimming Line of Pioneer Food Cannery in Ghana. Modern Economy. 2017, vol. 8, pp. 1561-1574.

[6] United Steel Industrial Company (Kuwait Steel) [online]. Available from: http://www.kwtsteel.com/KWTSteel

[7] Centers for Disease Control and Prevention [online]. Available from: https://www.cdc.gov/niosh/index.htm. 